\title{
HAMPEL GYÖRGY: Az elektronikus tananyag és keretrendszere
}

\begin{abstract}
Absztrakt: Számos elektronikus tananyag és a kezelését biztosító keretrendszer áll rendelkezésre az oktatás minden szintjén, szinte minden tudományterületen. Az elektronikus tanulás (e-learning) valamilyen elektronikus müszaki berendezéssel, elsősorban számítógéppel segített tanulás, amely lehet számítógéppel támogatott (CBT), web alapú (WBT), vagy kevert (blended) forma. A digitalizált anyag elkészítése, felhasználóhoz való eljuttatása és használata multimédia képességgel felruházott számítógépet igényel mind a fejlesztő, mind a tanuló oldaláról, továbbá - az esetek többségében - szélessávú internethálózatot. Az oktatóanyag elkészítéséhez használt szerzői rendszerek sokfélék: lehetnek laporientált, ikonnorientált, vagy időtengely orientáltak; egyesek csak felhaszálói szintü ismereteket igényelnek, mások programozási képességeket is. A tartalommenedzselést eltérő szolgátlatásokat nyújtó keretrendszerek (DMS, CMS, LCMS, LMS) végzik. A tartalmilag és technikailag tagolható elektronikus tananyag, valamint a keretrendszer minőségének biztosítására ISO és egyéb, a szakterület számára kidolgozott, bevált értékelési szempontok állnak rendelkezésre. A jó tananyag kidolgozása és a keretrendszer müködtetése erőforrásigényes, a várható haszna nehezen mérhető, de a 21 . században nem szabad figyelmen kívül hagyni ezt az oktatási formát; be kell illeszteni a hagyományos tanítási formák mellé.
\end{abstract}

Abstract: Several e-learning materials and their managing framework are available in all levels of education in almost every disciplines. E-learning means the use of some kind of technical equipment, primarily computers and can be called computer-assisted (CBT), web-based (WBT) or blended learning. Preparing, delivering and using the digitized material requires a computer with multimedia capabilities and in most cases broadband internet access on the side of the developer and the student as well. There is a variety of authoring tools to prepare the e-learning material: sheet-based, icon-based or timelinebased. Some of them require basic computer knowledge while others require programming skills too. Content management is provided by DMS, CMS, LCMS, LMS systems with different services. Proven evaluation criteria developed specially in this field and ISO standards help to ensure the quality of the e-learning material and the managing system as well. To make a good e-learning curriculum and to operate a learning management system is a resource intensive task and the expected benefits are difficult to measure, but this type of education cannot be ignored in the $21^{\text {st }}$ century; it should be used beside the traditional forms of teaching.

Kulcsszavak: e-tanulás, keretrendszer, szerzöi rendszer, szoftverminőség

Keywords: e-learning, learning management system, authoring system, software quality

\section{Bevezetés, célok}

$A z$ elmúlt húsz-harminc évben olyan kutatási eredményeket ismertető cikkek jelentek meg, amelyek azt igyekeznek igazolni, hogy az oktatási-tanulási tevékenység számítógépek bevonásával hatékonyabbá tehető (Sideridis et al., 2010). A fö (lehetséges) elönyöket a kutatók a következökben látják: tanulóközpontú, azaz a tanuló által irányított, a tanulónak megfelelö ütemü, interaktiv, gyakorlatias tanulási forma jön létre, amely rugalmas, konzisztens és eredményes képzést biztosít (National Institute of Justice, 2007). Ugyanakkor mások azt állítják, hogy a modern technológia alkalmazása nem csodaszer és mint ahogy 
egy, a virtuális tanulási környezetről szóló mühelymunka megállapítja: bár a számítógépek oktatásban történö alkalmazásának lehetnek potenciális elönyei, ezeket azonban nehéz tényeleges előnnyé változtatni, vagy a pozitív hatásokat mérni (Dillenbourg, 2000). Tulajdonképpen nem áll rendelkezésre kellö mennyiségü tudományos bizonyíték a korszerü technológiák oktatásban/tanulásban történő alkalmazásának elönyeire, hatásosságára.

Mindenesetre mára már számos elektronikus tananyag és a kezelését biztositó keretrendszer áll rendelkezésre az oktatás minden szintjén, szinte minden tudományterületen.

A cikk célja áttekintést adni:

- az elektronikus tanulásról, a digitális tananyagról,

- a megvalósitást és a hozzáférést biztosító rendszerekröl,

- a hardver és szoftver követelményekröl,

- a tananyag tartalmi és logikai tagolásáról, valamint

- a keretrendszer és tartalma minőségének értékelési lehetőségeiröl.

\section{Elektronikus tanulás, szerzői rendszer, keretrendszer}

Mindenekelött az „e-learning” (elektronikus tanulás, e-tanulás) fogalmát célszerü tisztázni. Lényegében valamilyen elektronikus müszaki berendezéssel, elsösorban számítógéppel segitett tanulási formáról van szó. Az e-learning fejlödés a távoktatáshoz kapcsolható; három szakasz különíthető el attól fưggően, hogy milyen eszközöket használtak fel a „hagyományos" - vagyis az oktató és a tanuló azonos térben és időben személyes jelenlétét igénylő - oktatáshoz képest (Szepesi, 2013).

Az első szakaszban, a 19. század első felében vezetik be az Egyesült Királyságban a levelezö oktatást, amely a posta által nyújtott szolgáltatásokat, ill. a levelezést használja fel az oktatás lebonyolítására.

A második szakasz már a 20. század elejére tehető. Ekkor kezdik alkalmazni rádiót; elöször szintén az Egyesült Királyságban, majd a következő évtizedekben egyre több fejlett országban. A rádió mellett elterjedtté válik a televízió használata is a század második felétöl.

A harmadik szakasz már a számítástechnika alkalmazásának korszaka. A személyi számítógép megjelenésével - majd elterjedésével az 1990-es évek közepére - kezd terjedni a számítógéppel támogatott oktatás/tanulás. A személyi számítógépek multimédia képességeinek (azaz a szöveg mellett hang, álló- és mozgókép megjelenítési képességeinek) általánossá válása, valamint ezen eszközök megfizethetővé válása lehetővé tette, hogy egyre több multimédia képességekkel felruházott oktatóanyag jelenjen meg számos területen az oktatás valamennyi szintjén. A fejlesztéseknek további lökést adott az internet világhálózat, majd a hordozható számítógépek és okostelefonok megjelenése, amely lehetöséget teremtett arra, hogy az elektronikus tananyagokat költséghatékonyan lehessen eljuttatni minden eddiginél nagyobb számú felhasználó (tanuló) felé.

A fentiek alapján, amikor e-learningröl beszélünk, akkor a távoktatásnak egy speciális változatára kell gondolnunk. Forgó és munkatársai (2003) definíciója szerint: „Az elearning, olyan számítógépes hálózaton elérhető nyitott - tér- és időkorlátoktól független -, képzési forma, amely a tanitási tanulási folyamatot megszervezve, hatékony, optimális, ismeretátadási, tanulási módszerek birtokában a tananyagot és a tanulói forrásokat, a tutortanuló kommunikációt, valamint a számítógépes interaktív oktatószoftvert, egységes keretrendszerbe foglalva, a tanuló számára hozzáférhetővé teszi" (Forgó et al., 2003: 81).

$\mathrm{Az}$ elektronikus tanulásnak három alapvető formáját különböztethetjük meg, ezek: A számítógéppel támogatott tanulás (CBT: Computer Based Training), a számítógép-hálózat- 
tal támogatott tanulás (WBT: Web Based Training), valamint az itthon kevert, vagy hibrid tanulási formának nevezett (Blended Learning) tanulási forma.

A CBT az informatikai eszközökkel megtámogatott „statikus” oktatási forma. A tananyag és az azt megjelenítő szoftverkörnyezet digitális adathordozón (mágneslemezen, vagy optikai háttértáron), vagy számítógép-hálózaton jut el a tanuló számítógépére. A tananyag „oktatója" és a tanuló között nincs semmilyen kapcsolat; menedzselt, kontrollált oktatásról nem, vagy csak nagyon szük értelemben beszélhetünk.

A WBT web alapú oktatás, ahol a tananyag az interneten keresztül jut el a tanuló számítógépére. Ez már menedzselt tanulás/oktatás, ahol szerepet kapnak a modern kommunikációs csatornák is, azaz a tanuló és az oktató elektronikus levelezővel, csevegő rendszerrel, fórumokon, sőt esetleg videokonferencia rendszeren keresztül tartják a kapcsolatot, ugyanakkor ez az oktatási-tanulási forma is teljesen nélkülözi az oktató és tanuló közötti személyes kapcsolatot.

A Blended Learning kevert oktatási mód, amely a webalapú oktatás mellett feltételezi az oktató és tanuló közötti személyes találkozót is meghatározott időközönként.

A fenti három tanulási-tanitási forma egymás mellett él. Mindháromnál a tanuló áll a középpontban, akinek van lehetősége arra, hogy megszervezze a saját tanulmányi elörehaladását (minél magasabb kompetenciaszinttel rendelkezik a tanuló, annál inkább képes erre). Az oktató (tutor) - amennyiben van - sok esetben csak, mint tanácsadó, mentor, és a tanulási folyamat végén, esetleg, mint a tudás értékelője jelenik meg.

\section{Hardver és szoftver}

Az elektronikus tananyag kifejlesztéséhez, a felhasználóhoz való eljuttatásához, ill. ahhoz, hogy a tanuló igénybe vegye a tanulásnak ezt a modern formáját, több technikai feltétel teljesítése szükséges:

A tananyagfejlesztéshez a nagy teljesítményü, multimédia-képességekkel rendelkező számítógép nélkülözhetetlen. Ez az éppen aktuális körülmények között, ill. általános trend szerint nagy teljesítményünek számító processzort, nagy tárolókapacitást biztosító operatív memóriát és háttértárat, grafikus kártyát és nagyfelbontású képmegjelenítö(ke)t, hangrögzítésre és hanglejátszásra alkalmas eszközöket feltételez számítógép-hálózati kapcsolattal, valamint a fejlesztéshez szükséges szoftver eszközökkel (multimédiát támogató operációs rendszerrel és ún. szerzői rendszerrel). A tananyagfejlesztő - aki sok esetben az oktató birtokában kell legyen a fejlesztéshez és az eszközök használatához szükséges tudásnak.

A tananyag tanuló gépére történő eljuttatásáról a szélessávú internet, ill. nagy tárolókapacitású háttértár gondoskodik. Webalapú oktatóanyag esetén gondoskodni kell a hálózati kiszolgálógép (szerver) üzemeltetéséröl, amely az elektronikus tananyag mellett müködteti az anyag eléréséhez szükséges keretrendszert, menedzseli a tanulók (az oktatók és az adminisztratív személyzet) jogosultságait, továbbá tárolja a tanulás menetével, az elörehaladással kapcsolatos adatokat is.

A tanulónak szintén rendelkeznie kell a tananyag elérését biztosító technikai eszközökkel: elegendően nagy teljesítményü, multimédia képességekkel felruházott számítógéppel, ill. okostelefonnal, azaz ügyfélgéppel (kliens) és többnyire szélessávú internetkapcsolat is szükséges. A tanulónak ezen felül rendelkeznie kell azokkal a kompetenciákkal, amelyek lehetővé teszik számára az eszközök használatát.

Elektronikus tartalmat bármiben lehet ,irni”; akár egy egyszerü szövegszerkesztő is használható. Mégis, a hatékonyság érdekében célszerü inkább olyan alkalmazásokat használni, amelyek kifejezetten elektronikus tartalomfejlesztésre lettek kitalálva. Ezek a szoft- 
verek a szerzői rendszerek. Ezeknek a rendszereknek a következő jól elkülöníthető csoportját különböztethetjük meg (Hardman, 1998; Szepes, 2013).

A laporientált szerzői rendszer az egyes tananyagegységeket oldalanként, laponként kezeli. Az viszont, hogy pontosan mit tekint egy lapnak, mekkora területet foglal el egy lap, az a rendszer által meghatározott. Ebbe a körbe tartoznak a bemutató-készitő programok (pl. Microsoft PowerPoint, LibreOffice Impress) és a HTML szerkesztök (weblapszerkesztök).

$\mathrm{Az}$ ikonorientált szerzői rendszerben a tartalmak, szolgáltatások ikonként állnak rendelkezésre, amelyeket egy folyamatábrára helyezve alakíthatjuk ki az alkalmazás múködését (pl. Adobe Authorware).

$\mathrm{Az}$ időtengely-orientált rendszerekben az elv hasonló, de itt a geometriai primitívekként, ill. lejátszást biztositó elemekként rendelkezésre álló szolgáltatásokat egy időfonalon helyezhetjük el (pl. Adobe Director, Adobe Flash).

A tananyag kezelése, tanulóhoz való eljuttatása az ún. keretrendszer feladata. Ez a több programot is magába foglaló rendszer szabályozza, hogy ki és hogyan férhet hozzá a tárolt ismeretanyaghoz. További feladatuk lehet még a tanulással kapcsolatos események, teljesítmények naplózása és kezelése. Egyes keretrendszerek szerzői rendszereket is tartalmaznak. Ezek a rendszerek a kínált fö szolgáltatások szerint sokfélék lehetnek, így létezik (a szolgáltatások fejlettségének sorrendjében):

- Dokumentumkezelö rendszer (DMS: Document Management System)

- Kurzus, ill. tartalomkezelö rendszer (CMS: Course/Content Management System)

- Tananyagkezelö rendszer (LCMS: Learning Content Management System)

- Tanulásirányítási (tanulásszervezési) rendszer (LMS: Learning Management System)

- LMS-nek tekinthető (bár jelenleg még nem minden szolgáltatást biztosít) a CooSpace és az ETR, valamint a Neptun zárt forráskódú rendszerek, amelyeket Magyarországon számos felsőoktatási intézményben használnak, ill. a Moodle, amely egy nemzetközi szinten elterjedt nyílt forráskódú ingyenes rendszer.

\section{Az elektronikus tananyag tagolása, elemei}

Az elektronikus tananyag tagolása tartalmi és technikai szempontok szerint lehetséges. A tartalmi tagolás szerint a tartalom felosztása a következö (Kőfalvi, 2006):

Kurzus: Ez a legnagyobb egység, a tananyag digitális változata. Egy-egy kurzus létezhet önállóan, vagy kapcsolódhat egy másik kurzushoz is, akár annak előfeltételeként. Terjedelme változó, függ a témától és a tanmenettől. Szerkezete a következőképpen épül fel: keretbe foglalja egy bevezető és egy összefoglaló oldal, valamint egy tudásfelmérő teszt.

Modul: A kurzus része; egy kurzuson belül általában több modul található, amelyeknek szerkezete hasonló a kurzusokéhoz, azaz az elején egy bevezető oldalból, a végén egy összefoglalóból és egy modulzáró tesztböl áll, ezek között található a lecke, ill. leckék. A modul egy jól körülhatárolt témakört dolgoz fel.

Lecke: Ez az oktatás alapegysége. A lecekék általában lineárisan követik egymást (hasonlóan a hagyományos oktatáshoz), de a keretrendszer megengedheti az ettől való eltérést is, például egy elözetesen kitöltött kompetenciateszt alapján. Feldoglozhat egy témát, fogalmat, modellt, egy-egy folyamatot, ill. eseményt. Tartalmazza a megtanulandó téma bemutatását, ezen kívül példákat, szimulációkat, a témához kapcsolódó játékokat, és a lecke végén akár tesztet is.

Jegyzék: A kurzushoz kapcsolódó törzsanyag-kiegészitések, amelyek többlet információval látják el az érdeklődő tanulókat, ill. a bizonyos információkat a tananyag mellett rendezetten adnak át (pl. fogalomtár, példatár, kép- és videoállományok gyüjteménye). 
A technikai tagolás azokat az objektumokat tartalmazza, amelyeket programozási szempontból érdemes elkuilöníteni a hatékonyabb megvalósítás érdekében. Ez a fajta tagolás segíti a tananyagfejlesztöt a tartalom átlátható megszerkesztésében és egyszerübbé teszi a programozást. A technikai elemek a következök:

Szöveg: Ez a tanulásra alkalmas, jól felépített szöveg, amelynek figyelembe kell vennie a tanulók tanulási elöfeltételeit és a tanuló számára érthetőnek kell lennie. A szöveget úgy kell felépíteni, hogy folyamatosan és egyenletesen közöljük az ismereteket és közben el kell kerülni a tanuló mentális túlterheltségét.

Vizuális elemek: Ez lehet kép, animáció, vagy videó. Elsősorban a szöveg kiegészítésére szolgál. Lehet leképező, bemutató funkciója, amely elősegíti, hogy a tanuló képet alkothasson egy adott témáról, tárgyról. Lehet szituációs funkciója, amikor is egy szituáció bemutatása, felidézése a cél. Konstrukciós funkcióról beszélünk akkor, ha a cél bonyolult valóságelemek, ill. folyamatok bemutatása (pl. képsorozat helyett mozgóképpel). Instrukciós funkcióról pedig akkor beszélünk, ha a képekkel utasításokat adunk, tájékoztatunk, vagy valamilyen cselekvési lehetőségre hívunk fel (pl. ikonokkal, amelyek segítik a tananyagban való tájékozódást, elörehaladást).

Akusztikai elemek: A hagyományos, jelenléti oktatáshoz elválaszthatatlanul hozzátartozik az oktató hangja. A tananyag hangzó formájú átadása fontos tényezö, hiszen más agyi területeket ingerel, mint a szöveg olvasása. A lehetőségek a következők: a teljes tananyag ill. csak bizonyos tananyagrészek felolvasása személy által, felolvasás hanggenetárottal, használhatók a szöveges és vizuális részeket kiegészítő hangos betétek (pl. zenei bejátszás), továbbá elhangozhatnak didaktikai funkciójú tanári közlemények is (pl. az oktató személyes megjegyzése a tananyaghoz, bevezető ill. záró gondolatok a tananyag elött és után).

Hipertext elemek: A hivatkozások lehetnek a szövegbe ágyazottak, amelyek funkciója az egyes tananyagegységek közötti átjárás megteremtése. Ezekel a belső hivatkozásokkal tud a tanuló gyorsan más tananyagrészekhez, vagy a jegyzékekhez hozzáférni. A szövegtől (általában) elkülönített külső hivatkozások arra szolgálnak, hogy a tananyagon kívüli, kiegészítő információk, dokumentumok elérését biztosítsák; ezek kivezetnek a tananyagból (pl. böngészőben nyitnak meg interneten elérhető honlapot). A hipertext elemek harmadik csoportja a tananyagon belüli navigációt biztosítja (pl. lapozás, ugrás), vagy valamilyen funkció elérése válik lehetővé a segítségével (pl. súgó, könyvjelző, saját jegyzetek).

\section{Az értékelés módszerei}

Mivel szoftverről van szó, a minősitésre használhatók az ISO szabványok, amelyek közül a legfontosabbak: ISO/IEC 9126 (Szoftverfejlesztés. Termékminőség) (Fahmi et al., 2012), ISO/IEC 25000:2005 és 25001:2007 (Szoftverfejlesztés. Szoftvertermék minőségi követelményei és értékelése), ISO/IEC 25010:2011 (Rendszer- és szoftverfejlesztés. Rendszerek és szoftver minőségi követelményei és értékelése. Rendszer- és szoftverminőségmodellek), ISO/IEC 25040:2011 (Rendszer- és szoftverfejlesztés. Rendszerek és szoftver minőségi követelményei és értékelése. Értékelési folyamat), ISO/IEC 25041:2012 (Rendszer- és szoftverfejlesztés. Rendszerek és szoftver minőségi követelményei és értékelése. Értékelési útmutató fejlesztőknek, beszerzőknek és független értékelőknek). Ezek a szabványok meghatározzák az értékelés menetét az szoftverértékelési szempontokat (Al-Qutaish, 2009), köztïk olyan minőségtulajdonságokat, mint a:

- Funkcionalitás (a célnak való megfelelỏség, pontosság, együttmüködési képesség, megfelelés, biztonság), 
- Megbízhatóság (érettség, hibatürő képesség, helyreállíthatóság),

- Használhatóság (érthetőség, megtanulhatóság, müködtethetőség),

- Hatékonyság (válasz- és végrehajtási idők, erőforrás-kihasználás),

- Karbantarthatóság (elemezhetőség, módosíthatóság, stabilitás, tesztelhetőség),

- Hordozhatóság (adaptálhatóság, telepithetőség, megfelelés, helyettesíthetőség).

Az elektronikus tananyagok és keretrendszerük értékelésére a fentieken túl egyéb ajánlások és szempontrendszerek sokasága áll rendelkezésre, így például a Heuristic Evaluation Instrument and Protocol for E-learning Programs (heurisztikus értékeló eszköz és protokol az e-learning programok értékelésére) (Benson et al., 2001), vagy az LMS Evaluation Tool User Guide (keretrendszer értékelő eszköz és felhasználói kézikönyv) (3waynet, 2004), ill. meg kell említeni (Forgó et al., 2003) komplex minősítési rendszerét is. Ezek és más szempontrendszerek egymással kombináltan alkalmazhatók (Sekhon és Hartley, 2014) a minél jobb minőségü végtermék elérése érdekében. Különösen fontos a fejlesztés, ill. az első kísérleti oktatás fázisában, hogy az értékelést a megbízótól a szerzőkön és az oktatókon át a tanulók is elvégezzék, és a visszajelzéseket beépítsék a tananyag és keretrendszer végleges változatába.

A svájci Edutech által ajánlott szempontok (Forgó, 2008):

- A tanulói környezet értékelése: A tanulóközpontúságnak megfelelően kifogástalan tanulói környezetet kell biztosítani, ahol meg kell oldani a tananyaghoz való folyamatos és azonosított formában való hozzáférést, valamint azt, hogy a tanuló saját igényeinek megfelelően alakíthassa ki a saját felhasználói környezetét. Fontos szempont, hogy a tanuló képes legyen tartani a kapcsolatot az oktatójával és tanulótársaival is, szövegesen, ill. audiovizuális eszközök segítségével. Emellett a rendszernek olyan eszközöket is kell tartalmaznia, amelyek lehetővé teszik a csoportmunka generálását, és amelyek képesek mutatni a tanulók előrehaladását is.

- A szerzői környezet értékelése: Fontos eldöntendő kérdés, hogy a tananyagfejlesztés megvalósításához mik a szerzői környezettel kapcsolatos elvárások: Elegendő-e a tananyagfejlesztök részéröl a „felhasználói szintü” ismeret, vagy szükség van programozói tudásra is? Tartalmazzon-e beépitett szerkesztőt? Szükség van-e közös munkavégzésre? Kell-e tesztszerkesztő, ill. milyen típusú tesztek hozhatók létre, stb.?

- A tanári környezet és módszerek értékelése: Azt érdemes vizsgálni, hogy a rendszer ad-e lehetőséget a nevelői/oktatói szerep gyakorlására, van-e lehetőség csoportmunka kialakítására, a részvétel nyilvántartására, a tanulók munkájának naplózására, értékelésére.

- Az adminisztráció értékelése: A keretrendszer azon szolgáltatásainak vizsgálata is fontos, amelyek lehetőséget biztosítanak a résztvevők regisztrációjára, a hozzáférési jogosultságok megadására/megvonására.

- Egyéb, általános tulajdonságok értékelése: A fontosabb, vizsgálandó tulajdonságok a többnyelvüség, a tananyag szabványok támogatása (pl. SCORM), a többplatformúság, a más rendszerekkel való együttmüködési képesség, a rendszer megbizhatósága, stabilitása és dokumentáltsága. Természetesen nem elhanyagolható szempont a rendszer beszerzésével, müködtetésével és karbantartásával kapcsolatos költségek sem.

Ezeken felül magának a digitalizált tartalomnak az értékelésére, minősítésére is több, eltérő megközelitést alkalmazó modell áll rendelkezésre (Attwell, 2006), amelyek kiterjednek annak megválaszolására, hogy mennyire képes a tananyag teljesíteni a kitüzött pedagógiai, tanulási, pénzügyi és egyéb, a megbízó/fejlesztő/tanuló által megfogalmazott elvárásokat. 


\section{Zárszó}

Az infokommunikációs technológia fejlettsége és hozzáférhetősége a 21. században Magyarországon lehetővé teszi, hogy bárki bármikor fejlessze tudását. A digitalizált tananyagok elöállitására és eljuttatására különböző képességü keretrendszerek sokasága áll rendelkezésre. Mind a tananyag, mind pedig a keretrendszer minőségének értékelésére és javítására kipróbált módszertanok léteznek.

Bár vannak, akik vitatják a modern technológia - hagyományos módszerekkel szembeni - hatékonyságát az oktatásban, nem elhanyagolható az a tény, hogy egyre többen alkalmazzák a tanulásnak az informatikai eszközökkel támogatott formáját. Egy olyan új trendrỏl van szó, amely - ha nem is helyettesítheti minden területen, de - jól kiegészíti a meglévő, már bevált módszereket a tudás átadásában.

Tény, hogy sok erőforrás ráfordítást (időt, pénzt, eszközöket stb.) követel egy valóban jó tananyag elkészitése, folyamatos fejlesztése és oktatásban való alkalmazása, azonban nem szabad elfelejteni, hogy itt is - mint egy informatikai beruházásnál, ahol a költségek jól meghatározhatók, míg az elönyök, csak mint könnyen vitatható közvetett hasznok jelenithetők meg (Hetyei, 2009) -, a szigorú költség-haszon elemzés helyett célszerü inkább az új technológia alkalmazása elmaradásának következményeit mérlegelni.

\section{Irodalomjegyzék}

Al-Qutaish, R. E. (2009): Measuring the Software Product Quality during the Software Development Life-Cycle: An International Organization for Standardization Standards Perspective. Journal of Computer Science, 5 (5), 392-397.

Attwell, G. (szerk.) (2006): Evaluating E-learning. A Guide to the Evaluation of E-learning. Evaluate Europe Handbook Series Volume 2, Pontypridd, Wales <http://www.pontydysgu.org/ wp-content/uploads/2007/11/eva europe vol 2 prefinal.pdf $>$ (2013.09.09.)

Benson, L., Elliott, D., Grant, M., Holschuh, D., Kim, B., Kim, H., Lauber, E., Loh, S., Reeves, T. (2001): Heuristic Evaluation Instrument and Protocol for E-Learning Programs, University of Georgia <http://treeves.coe.uga.edu/edit8350/heureval.rtf $>$ (2015.01.05.)

Dillenbourg, P. (2000): Virtual Learning Environments. Workshop on virtual learning environments. Learning in the New Millennium: Building New Education Strategies for Schools, Genf. <http://tecfa.unige.ch/tecfa/publicat/dil-papers-2/Dil.7.5.18.pdf> (2013.09.09.)

Fahmi, S., Haslinda, N., Roslina, W., Fariha, Z. (2012): Evaluating the Quality of Software in e-Book Using the ISO 9126 Model. International Journal of Control \& Automation, 4 (5), 115-122.

Forgó S., Hauser Z., Kis Tóth L. (2003): A-learning kurzusok, és tananyagok minőségbiztosítási kérdései. Bolyai Szemle, 12 (2), 79-99.

Forgó S. (2008): A médiaértékeléstől a kreatív alkalmazásig. In: HEFOP 3.3.31 és HEFOP 3.3.2 pályázat. EKF, Eger.

Hardman, H. L. (1998): Modelling and Authoring Hypermedia Documents. <http://homepages.cwi.nl/ $\sim$ lynda/thesis/> (2015.01.12.)

Hetyei J. (szerk.) (2009): ERP rendszerek Magyarországon a 21. században. Computerbooks, Budapest.

Köfalvi T. (2006): E-tanitás: információs és kommunikációs technológiák a közoktatásban. Nemzeti Tankönyvkiadó, Budapest.

National Institute of Justice (2007): DNA Analyst Training: Benefits of e-Learning. NFSTC Science Serving Justice, <http://projects.nfstc.org/pdi/Subject00/pdi_s00_m03_02_a.htm> (2013.09.09.)

Sekhon, M., Hartley D. (2014): Basics of E-learning Revisited. $T \bar{D}$ at $\bar{W} o r \bar{k},<$ https://www.td.org/ Publications/TD-at-Work/2014/Basics-of-E-Learning-Revisited $>$ (2015.02.10.)

Sideridis, A. B., Koukouli, M., Antonopoulou, E. (2010): ICT and farmers: lessons learned and future developments. Journal of Agricultural Informatics, 1 (2), 35-41.

Szepesi J. (2013): Az elektronikus tanulás és a könyvtárak. Németh László Városi Könyvtár, Hódmezővásárhely. <http://mek.oszk.hu/12500/12537> (2015.01.12.) 